\title{
O lugar da dramaturgia nas histórias da literatura brasileira
}

\author{
João Roberto Faria
}

$\checkmark$ á muitos anos trabalhando na interface da literatura com o teatro, vou tratar aqui de uma questão que me intriga quando leio as histórias da literatura brasileira do passado e do presente: qual é ou qual deve ser o lugar da dramaturgia na história da literatura? Essa pergunta pode ser desdobrada em outras: as peças teatrais devem ser estudadas como obras literárias, ao lado de poemas, contos e romances? Ou: as peças teatrais devem ser estudadas apenas nas histórias do teatro e nas histórias da dramaturgia? Ou ainda: as peças teatrais devem ser estudadas tanto nas histórias da literatura quanto nas histórias do teatro? E, por fim, a questão que pretendo abordar - que espaço as histórias da literatura brasileira têm reservado para a dramaturgia? - e que me fará comentar as outras, sem dar respostas definitivas, dada a complexidade do assunto.

Para aplainar o terreno, convém observar que historicamente a dramaturgia tem sido estudada como parte da literatura e que já em Platão e Aristóteles o gênero dramático divide com o épico e o lírico o fazer literário dos poetas. Aliás, na Poética, Aristóteles deixa claro o seu ponto de vista, segundo o qual uma tragédia vale pelo texto em primeiro lugar e que o espetáculo vem depois em importância.

Se avançarmos nos séculos, constataremos que o papel de grandes dramaturgos foi muitas vezes o de enriquecer a literatura de seus países. A ninguém ocorrerá tirar Shakespeare da história da literatura inglesa e muito menos Racine, Corneille e Molière da história da literatura francesa. Quererá isso dizer que estou trazendo para a discussão um falso problema?

$\mathrm{Na}$ verdade, apenas no final do século XIX é que o teatro começou a afirmar-se como arte autônoma, na qual uma peça teatral é considerada apenas como parte do espetáculo, que se realiza com a colaboração de outros fazeres artísticos: o do ator, o do iluminador, o do cenógrafo, o do figurinista, todos trabalhando sob a batuta de um novo demiurgo: o encenador. No nosso tempo, ninguém mais pensa como Aristóteles, que o espetáculo é coisa secundária. Ao contrário, é a partir do que ocorre no palco que se deve escrever as histórias do teatro.

Se antes de André Antoine - o primeiro encenador moderno, criador do Théâtre Libre, em Paris, em 1887 - o espetáculo teatral já reunia eventualmente vários fazeres artísticos, não

João Roberto Faria é Professor Titular do Departamento de Literatura Brasileira da FFLCH-USP. Este texto foi apresentado no IV Seminário Nacional de História da Literatura, realizado na Universidade Federal do Rio Grande, entre 13 e 15 de outubro de 2010. 
havia ainda uma autoridade, ou melhor, uma assinatura, um trabalho autoral e artístico responsável pela unidade da montagem teatral. $\mathrm{O}$ que havia era a supervisão do ensaiador, que distribuía os papéis de acordo com a idade e o tipo físico dos atores de uma determinada companhia e fazia a "marcação" do espetáculo, isto é, determinava aos artistas sua posição no palco, dividido em nove espaços que eram ocupados quase sempre da seguinte maneira: no centro, o primeiro ator ou a primeira atriz; à sua volta, os demais. Com o surgimento do encenador, uma nova história começa: a do teatro, na qual a literatura dramática não é mais hegemônica, uma vez que a arte teatral é essencialmente uma arte cênica. Até o final do século XIX, porém, a história do teatro se confundia com a história da literatura dramática, esta embutida na história da literatura.

Exemplos desse entendimento não faltam, nem nas histórias da literatura na Europa, nem nas histórias da literatura brasileira. No século XIX, para ficarmos em nosso território, já na inaugural História da Literatura Brasileira, obra incompleta de Joaquim Norberto de Sousa Silva (publicada entre 1857 e 1862 na Revista Popular), a dramaturgia de Anchieta - melhor dizendo, o pouco que se conhecia dela, o auto intitulado Pregação Universal - merece destaque junto aos poemas dos tempos coloniais. Já as comédias de Botelho de Oliveira são apenas mencionadas, sem qualquer comentário. Lembre-se ainda que em obra anterior, Bosquejo da História da Poesia Brasileira (1840-1841), Joaquim Norberto comenta as comédias de Antônio José da Silva, o Judeu, incluindo o escritor na literatura brasileira por ter nascido no Rio de Janeiro. Há nessa obra breves considerações críticas sobre as tragédias de Gonçalves de Magalhães, Antonio José ou o Poeta e a Inquisição e
Olgiato, bem como sobre o Prólogo Dramático de Araújo Porto-Alegre. Observe-se mais uma vez que essas peças de teatro são comentadas no interior de uma história da poesia brasileira.

O teatro entendido como literatura aparece também no Curso Elementar de Literatura Nacional, do cônego Joaquim Caetano Fernandes Pinheiro, de 1862. Mas nessa obra um tanto confusa, em que se mistura a literatura brasileira com a portuguesa, não há muito que ressaltar. $\mathrm{O}$ autor também se refere a Antônio José como "nosso dramaturgo" e elogia seu talento cômico (cf. Fernandes Pinheiro, 1862, p. 455). Decepciona a parte em que estuda o teatro romântico. Martins Pena não é mencionado e só encontramos breves referências às tragédias de Gonçalves de Magalhães e às peças $O$ Cavaleiro Teutônico, de Teixeira e Souza, e O Fantasma Branco, de Joaquim Manuel de Macedo.

Um pouco mais completa no plano informativo é O Brasil Literário: História da Literatura Brasileira, do austríaco Ferdinand Wolf, datada de 1863. O autor comenta o auto Pregação Universal, de Anchieta, ${ }^{1}$ e arrisca uma opinião crítica acerca das comédias de Botelho de Oliveira, escritas em espanhol. A seu ver, Hay Amigo para Amigo e Amor, Enganos e Celos não revelam nenhum talento dramático: "O diálogo é verboso, a exposição muito lenta, as numerosas expectoraçōes líricas só servem para disfarçar a falta de ação" (Wolf, 1955, p. 43-4). Ainda no que diz respeito ao teatro dos tempos coloniais, dá informações sobre representações no século XVIII, revelando a pobreza da vida teatral naqueles tempos:

Vimos que nos meados do século XVIII, a poesia lírica é a única que apresentou desenvolvimento razoável no Brasil. E ainda esta

1 Tanto Joaquim Norberto quanto Ferdinand Wolf se baseiam na obra Vida do Venerável Padre Joseph de Anchieta da Companhia de Jesu, Taumaturgo do Novo Mundo na Provincia do Brasil, de Simam Vasconcellos (Lisboa, Oficina de Ioam da Costa, MDCLXXII), na qual estão preservados dois fragmentos do auto Pregação Universal. 
poesia era toda de imitação, sem raízes no povo e não tinha para distingui-la mais que uma ligeira cor local. Nestas circunstâncias, e em vista da falta de uma base popular e de um caráter nacional, bem pronunciado, não é surpreendente que não se tenha ainda produzido um drama nacional, e tanto tinha que ser assim que a poesia do tempo não revelava nada de épico. A civilização, além do mais, era bastante incerta para fazer sentir necessidade de uma cena regular.

Os únicos ensaios dramáticos do primeiro período foram ou mistérios religiosos, ou então produções que não chegaram a serem apresentadas, talvez por não terem sido escritas com esta finalidade. Além disto, viramse, às vezes, representações teatrais nas festas da corte. Não apenas danças, mímicas ou entremezes, como ainda comédias propriamente ditas. Infelizmente, estas peças eram escritas em espanhol e os próprios atores representavam-nas nesta língua. Assim, sabemos que, em 1717, foram representadas na Bahia as duas comédias de Calderon El Conde Lucanor e Afectos de Odio e Amor. Em 1729, para a festa do duplo casamento dos príncipes reais de Espanha e Portugal com a infanta Maria Bárbara de Bragança e Maria Ana Vitória de Bourbon foram representadas as peças do mesmo poeta intituladas Fineza contra fineza, La fiera, el rayo y la piedra e El monstruo de los jardines, assim como as comédias de Moreto: La fuerza del natural e $E l$ desden con el desden". ${ }^{2}$

O destaque no período fica por conta das comédias - ou óperas, como eram chamadas de Antônio José, que ganham largo comentário crítico. Curiosamente, Ferdinand Wolf exclui e depois inclui o escritor na literatura brasileira. Inicialmente, escreve: "O autor de peças conhecidas sob o nome de Óperas do Judeu, só é, na verdade brasileiro de nascimento e pertence a Portugal por sua cultura e atividade. O que apesar disto nos leva a falar dele nesta obra, é o desejo de aproveitarmo-nos desta ocasião para tornar conhecidos, em torno de um dos homens mais bem dotados do Brasil, um certo número de fatos, que os últimos anos trouxeram completamente à tona" (Wolf, 1955, p. 56). Depois de analisar as peças, parece ter mudado de opinião sobre o lugar de Antônio José na literatura brasileira: "Estas obras de um poeta brasileiro, que fez época na literatura portuguesa, e que tem tido influência mais duradoura ainda, se tivesse tido sucessores, capazes de purificarem o gosto nacional e de manterem afastado o pseudo-classicismo francês, ultimamente voltaram a merecer consideração reconquistando o seu lugar na literatura brasileira" (idem, p. 75).

Sabe-se que Ferdinand Wolf escreveu seu livro com muitos subsídios que lhe foram passados por Gonçalves de Magalhães, Araújo Porto-Alegre e Ernesto Pereira França. Ora, Gonçalves de Magalhães havia estreado no teatro, em 1838, com uma tragédia sobre Antônio José, considerado por ele um escritor brasileiro. No prólogo à peça, deixou isso bem claro ao afirmar: "Desejando encetar minha carreira dramática por um assunto nacional, nenhum me pareceu mais capaz de despertar as simpatias e as paixões trágicas do que este. As desgraças de um literato, de um poeta, que concorreu para glória nacional, não podem deixar de excitar interesse e amor, ao menos em nosso país" (Faria, 2001, p. 326).

Nos tempos românticos, de nacionalismo exacerbado, bastava o fato de Antônio José

2 Cf. Cap. IV, "Ensaios dramáticos - Estado do teatro no Brasil - as Óperas do judeu Antônio José da Silva". Ferdinand Wolf lembra ainda que "José Borges de Barros, conhecido principalmente como cronista e orador sacro (vigário geral de Coimbra e de Évora, nascido na Bahia em 1657, morto em Estremoz em 1719) também se ensaiou como autor dramático. Uma só de suas comédias $A$ constância com triunfo chegou aos nossos dias". 
ter nascido no Brasil para que fosse considerado escritor nacional. Ferdinand Wolf talvez tenha se dobrado ao argumento de Gonçalves de Magalhães.

Ainda em relação ao teatro, o autor dedica o capítulo XVII de sua obra ao "Progresso da poesia dramática” no romantismo. Suas considerações críticas são prejudicadas pelo fato de não ter lido muitas das peças que menciona. Assim, Gonçalves de Magalhães aparece como o grande nome do período, ao passo que Martins Pena merece apenas dois parágrafos, nos quais se reconhece a graça do "diálogo vivo e cheio de ditos de espíritos populares", porém prejudicado por vezes pelo "sal muito grosseiro" (idem, p. 339). Já publicado em 1847, o belo drama Leonor de Mendonça, de Gonçalves Dias, não foi lido por Ferdinand Wolf. De Joaquim Manuel de Macedo o autor comenta apenas o drama Cobé e as comédias O Primo da Califórnia e O Fantasma Branco, condenando a última por ser uma farsa.

Ainda que os comentários críticos de Ferdinand Wolf sejam fracos, ao incluir referências às peças dos autores acima citados e de Joaquim Norberto, Varnhagen, Teixeira e Souza, Luís Antônio Burgain, Martim Francisco Ribeiro de Andrada, Cândido José da Mota e Pinheiro Guimarães, ele forneceu uma base para os futuros trabalhos historiográficos sobre o teatro brasileiro em seu momento de formação. Mas não nos esqueçamos: o teatro entendido aqui como realização dramática.

Resta ainda observar uma incongruência no capítulo dedicado ao teatro. $\mathrm{Na}$ lista de autores dada acima, o nome de Pinheiro Guimarães destoa dos demais, porque sua peça História de uma Moça Rica, encenada em outubro de 1861, não faz parte do repertório romântico.
Representada no Teatro Ginásio Dramático, no Rio de Janeiro, dialoga com as comédias do realismo teatral francês, que vinham sendo encenadas desde 1855. Além disso, citar Pinheiro Guimarães e nenhum dos outros dramaturgos que vinham se revelando na cena do Ginásio, desde 1857, José de Alencar à frente de todos, não tem muito sentido. Antes de Pinheiro Guimarães, houve várias estréias, algumas muito bem-sucedidas. Alencar fez sucesso com as comédias $O$ Rio de Janeiro, Verso e Reverso, $O$ Demônio Familiar e o drama Mãe; fracassou com O Crédito e teve a comédia As Asas de um Anjo, proibida pela polícia. Sua trajetória como dramaturgo era do conhecimento de Gonçalves de Magalhães e Porto-Alegre. Teria o primeiro se vingado das críticas que lhe fez Alencar por ocasião do lançamento da Confederação dos Tamoios, em 1856, nada dizendo das peças de seu desafeto a Ferdinand Wolf? É possível. Igualmente não foram lembrados outros dramaturgos que estrearam no Ginásio antes de Pinheiro Guimarães: Quintino Bocaiúva, com as peças Onfália e Os Mineiros da Desgraça; Joaquim Manuel de Macedo, com Luxo e Vaidade; Aquiles Varejão, com A Época; Sizenando Barreto Nabuco de Araújo, com $O$ Cínico; e Valentim José da Silveira Lopes, com Sete de Setembro.

\section{2}

As obras de Joaquim Norberto, Fernandes Pinheiro e Ferdinand Wolf, além de outras que trataram secundariamente da literatura brasileira - História da Poesia e Eloqüência Portuguesa, ${ }^{3}$ de Friedrich Bouterwek (1805); De la Littérature du Midi de l'Europe, ${ }^{4}$ de Simonde de Sismondi (1813); Résumé de l'Histoire Littéraire du

3 Apenas dois autores nascidos no Brasil são estudados na obra de Bouterwek: Antônio José da Silva e Cláudio Manuel da Costa, ambos considerados autores da literatura portuguesa.

4 Na esteira de Bouterwek, Sismonde de Sismondi analisa a obra de três escritores nascidos no Brasil, Antônio José da Silva, Cláudio Manuel da Costa e Manuel Inácio da Silva Alvarenga, considerando-os autores da literatura portuguesa. 
Portugal et du Brésil, 5 de Ferdinand Denis (1826) - e de outros escritos historiográficos publicados em revistas literárias ${ }^{6}$ mapearam o terreno e prepararam o surgimento da primeira história da literatura brasileira realmente importante, a de Sílvio Romero, de 1888. O autor fez uma segunda edição, em 1902, e vale a pena verificar como ele situa a dramaturgia no interior da literatura brasileira.

No primeiro volume, nada há sobre o Anchieta dramaturgo. Seus autos não eram ainda conhecidos. O autor também nada escreve sobre as comédias de Botelho de Oliveira, mas em compensação reserva bom espaço para as comédias de Antônio José. A seu ver, o escritor deve ser contemplado na história da literatura brasileira, por três razōes principais: "o nascimento, a família, que sendo também fluminense, inoculou-lhe n'alma o sentimento nacional, e, finalmente, a natureza de seu lirismo, que é brasileiro" (Romero, 1902, p. 163).

$\mathrm{O}$ argumento nacionalista, de fundo romântico, ainda pesa nas formulações de Sílvio Romero. Ele cita Ferdinand Wolf e Teófilo Braga, concordando com os elogios que ambos fazem ao sabor popular e à linguagem do povo que o comediógrafo emprega. Mas nem eles nem Machado de Assis ou Varnhagen enxergaram "o caráter brasileiro de Antônio José ou o seu grande talento lírico, o que é o mesmo" (idem, p. 164). Para Romero, não foi apenas a facilidade de fazer pilhérias que tornou o comediógrafo famoso em seu tempo. A essa qualidade ele acrescenta a do poeta lírico, valorizando a qualidade literária de seus textos.

Antes de avançarmos, registre-se que ao comentar as obras dos poetas árcades, Romero dá poucas informações sobre as atividades teatrais nas cidades mineiras, lembrando apenas que Inácio José de Alvarenga Peixoto escreveu um drama em versos, Eneias no Lácio, e traduziu a Merope, de Maffei, trabalhos perdidos. Tudo indica que não teve em mãos o pequeno drama O Parnaso Obsequioso, de Cláudio Manuel da Costa, representado em Vila Rica em 1768.

No segundo volume de sua obra, dedicado ao romantismo, Romero faz duros comentários às primeiras peças escritas no final da década de 1830 e início da seguinte. Considera acertadamente que "não tiveram grande influência" as produções dramáticas de Porto Alegre, Joaquim Norberto e Ernesto França. Mas erra ao colocar Gonçalves de Magalhães entre esses escritores. Já era consenso em 1888 entre os intelectuais brasileiros que a encenação de Antônio José ou o Poeta e a Inquisição, em março de 1838 , inaugurara o teatro romântico no Brasil, com sucesso, em boa parte por causa da interpretação do papel principal pelo ator João Caetano. Difícil saber por que Romero não deu esse crédito a Gonçalves de Magalhães. Talvez por avaliar com excesso de rigor a tragédia do poeta, a seu ver "uma obra incolor, sem vida, sem um só tipo verdadeiramente acentuado, sem ação dramática” (Romero, 1903, p. 27).

Com o mesmo rigor, o autor julga as peças de Araújo Porto-Alegre, Teixeira e Souza e Joaquim Norberto, reservando, porém, e acertadamente, elogios ao "belíssimo drama" Leonor de Mendonça, de Gonçalves Dias, bem como ao prólogo em que o poeta expõe o seu pensamento sobre o teatro. Nas páginas dedicadas ao escritor maranhense há, porém, uma informação errada, relativa à ação do Conservatório Dramá-

5 Ao contrário de Bouterwek e Simondi, Ferdinand Denis separa a literatura portuguesa da brasileira em seus comentários, estimulando os brasileiros a criar uma literatura própria e já sintonizada com o romantismo. Como as atividades teatrais ainda são parcas no Brasil, não faz observações críticas sobre a dramaturgia.

6 Por exemplo: "Bosquejo da história da poesia e língua portuguesa", de Garrett, e "Discurso sobre a história da literatura do Brasil”, de Gonçalves de Magalhães. Cf. Maria Eunice Moreira, Nacionalismo Literário e Crítica Romântica, Porto Alegre, IEL, 1991. 
tico, que teria posto "embaraços" à representação do drama, "a pretexto de ser incorreto de linguagem". Na verdade, o drama Beatriz Cenci é que foi proibido de ser representado pelo Conservatório. Leonor de Mendonça foi liberado, mas o ator João Caetano não quis encená-lo.

Simpático aos esforços dos primeiros brasileiros que escreveram para o teatro, Romero observa que as companhias dramáticas poderiam encenar "sempre" os dramas de Gonçalves Dias e de outros autores, como Agrário de Menezes, Martins Pena, Joaquim Manuel de Macedo e José de Alencar. "De vez em quando", acrescenta, também seria conveniente pôr em cena "alguma coisa dos velhos, Magalhães, Porto-Alegre, Norberto Silva, Ferreira França e dos mais modernos Varejão, Castro Lopes, Machado de Assis, Távora e muitos brasileiros que têm cultivado o gênero" (Romero, 1903, p. 182).

A escolha desses autores deixa entrever o ponto de vista de Romero, que vê o teatro como literatura. Esse ponto de vista é reforçado numa passagem em que, comentando o prólogo de Gonçalves Dias a Leonor de Mendonça, escreve:

Diz-se vulgarmente que uma obra dramática só é bem apreciada quando é vista no palco. O próprio Gonçalves Dias o repete no aludido prólogo: "Se o drama não for representado, será bom como obra literária, mas nunca como drama".

Tenho medo de dizer uma heresia; porém, pelo que me toca, aprecio mais os dramas, especialmente, dos grandes mestres, quando os leio. Se, além da leitura, ocorrer uma boa representação, meu conhecimento da obra não aumentará grande coisa, quanto à obra literária em si.

Se nunca li o drama e só o vi representar, nada sei dizer sobre ele, porque o que apreciei no palco foi o trabalho dos atores, sua voz, seus gestos, seu jogo cênico, seu savoir dire e savoir faire em cena, e não a criação do poeta diretamente.

Uma representação teatral é uma arte que se sobrepõe à outra e a vela em grande parte.
O talento dos atores produz uma como segunda criação que pode até certo ponto dificultar a exata inteligência da primeira.

Nunca vi os dramas de Gonçalves Dias em cena. Creio não ser um empecilho para os apreciar (Romero, 1903, p. 184-5).

O que se deve observar nessa passagem, em primeiro lugar, é o pensamento moderno de Gonçalves Dias: uma peça teatral é feita para ser encenada; é no palco que ela ganha vida. Se é apenas lida, diz o poeta, ela pode ser boa como obra literária, não como teatro. Sílvio Romero também faz a distinção entre uma arte teatral a da peça encenada - e uma arte literária - a da peça lida -, mas defendendo um ponto de vista contrário, ou seja, o de que a leitura permite uma apreciação direta do texto, e portanto melhor, sem a interferência do trabalho dos atores. Nessa passagem, fica muito claro o entendimento da dramaturgia como literatura. Aliás, isso é perceptível nos dois primeiros capítulos do volume, nos quais são estudados lado a lado os romances, os poemas e as peças teatrais dos autores do nosso primeiro romantismo.

No início do terceiro capítulo Romero pede ao leitor que não se espante por não ver entre os poetas os nomes de Joaquim Manuel de Macedo e Machado de Assis: "eles e outros irão figurar entre romancistas e dramaturgos" (Romero, 1903, p. 195), anuncia. Mais à frente, diz o mesmo sobre Agrário de Menezes. Quando chegamos ao final do volume e constatamos que o estudo da poesia romântica consumiu todas as páginas, fica-nos a impressão de obra inacabada.

De fato, um terceiro volume deveria ter sido publicado, para dar conta da prosa e da dramaturgia. $\mathrm{O}$ autor faleceu sem ver sua obra completa editada. Em 1943, seu filho Nelson Romero reorganizou a História da Literatura Brasileira em cinco volumes, incluindo outros estudos do pai e a parte relativa aos romancistas e dramaturgos. Vale a pena ler o início do capítulo intitulado "Terceira Época ou Período de Transformação Romântica (Prosa) - Teatro e 
Romance”. Sílvio Romero define o método que empregou para estudar escritores que praticaram mais de um gênero literário:

O método adotado neste livro, sendo o de contar a história da literatura nacional por épocas e não por gêneros, e tendo sido, além disso, tomado o alvitre de se colocar cada escritor na especialidade em que mais se tenha distinguido, forçoso é juntar o Teatro e o Romance nos vários capítulos em que vão ser explanados estes dois assuntos; porque os melhores cultores da dramaturgia o foram também do romance no Brasil.

Inconveniente seria estar a voltar sobre o mesmo autor em diversas paragens da narrativa a propósito das múltiplas e variadas manifestações que, porventura, tenha dado o seu talento. Escritor estudado, deve sê-lo de vez, para se lhe não perder o tom da característica, nem apagar a feição inteiriça da individualidade espiritual. Destarte, vai este livro dizer agora de Martins Pena, Joaquim Manuel de Macedo, José de Alencar, Agrário de Menezes, Manuel de Almeida, Pinheiro Guimarães, Machado de Assis, Escragnolle Taunay, Franklin Távora e outros polígrafos, que de tudo escreveram um pouco; mas no teatro e no romance é que deveras se distinguiram (Romero, 1980, p. 1350).

O que se segue é um longo e entusiasmado estudo das comédias de Martins Pena, que Romero havia publicado separadamente em 1901 (cf. Romero, 1901). Abundam nessas páginas os elogios à capacidade de observador dos costumes do nosso primeiro comediógrafo, bem como à habilidade de colocar os personagens em situaçôes burlescas que desencadeiam necessariamente o cômico. A seu ver, Martins Pena iniciava uma tradição de comédias por meio das quais se podia conhecer a sociedade brasileira, especialmente seus vícios e problemas, como a escravidão. Nesse sentido, afirma o historiador, sua obra era mais importante que a de Gonçalves de Magalhães, encenada com pompa por
João Caetano. Além dessas corretíssimas observações, a certa altura do texto ele faz um interessante resumo das atividades teatrais que se seguiram ao aparecimento de Martins Pena:

O nosso comediógrafo é a documentação viva dos primeiros cinquenta anos deste século no Brasil. Neste sentido leva decidida vantagem a todos os escritores de seu tempo, nomeadamente aos autores dramáticos. Estes, entre nós, se podem dividir em três grupos, que correspondem a três fases diversas do teatro e da vida nacional. O primeiro é dos espíritos entusiastas que pretenderam no decênio de 1838 a 1848 criar neste país a literatura da cena. O mais notável deles foi incontestavelmente o ilustre autor dos Irmãos das Almas, com seus dramas e comédias, especialmente com estas últimas. Domingos Magalhães foi o segundo em importância, seguindo-se Gonçalves Dias, que deu ao teatro três ou quatro dramas e Araújo Porto-Alegre, que escreveu algumas comédias. Igual a todos estes foi certamente L. A. Burgain, francês de origem e brasileiro na ação e nos feitos. A esta fase pertenceu Norberto e Silva, que produziu tragédias, dramas e comédias, tudo de valor muito negativo. O segundo grupo formou-se daqueles moços generosos, plêiade de homens de talento que, de 1856 a 1863 ou 64, procuraram reerguer o teatro no Brasil, levantando-o do abatimento em que tinha caído. Manuel de Macedo que, aliás, vinha da época antecedente, Agrário de Menezes, este na Bahia, José de Alencar, Pinheiro Guimarães, Aquiles Varejão, Castro Lopes, Constantino Gomes de Sousa, Augusto de Castro foram entre eles os mais notáveis. A terceira e última falange é a dos trabalhadores contemporâneos, a datar dos anos próximos a 1870 até os nossos dias. Que o saibamos, os mais ilustres então têm sido França Júnior, já hoje morto e que vinha do período anterior, os dois irmãos Artur e Aluísio Azevedo. Outros há agora aí que se têm metido a escrever para o teatro; mas são tão inferiormente nulos, que 
ficaria para sempre maculada a pena de escritor sério que deles se ocupasse (Romero, 1980, p. 1365-6).

A citação é longa, mas eis aí um balanço quase sempre correto da produção dramática brasileira do século XIX. Poderíamos acrescentar os nomes de Quintino Bocaiúva e de Machado de Assis, além de outros menores, para a lista ficar mais completa, mas o que parece importante notar é o número pequeno de autores do terceiro período. O fato é que o teatro sério, de cunho literário, sofreu uma enorme concorrência do teatro cômico e musicado nas últimas três décadas do século. Operetas, mágicas (a féerie francesa) e revistas de ano tornaram-se hegemônicas nos teatros do Rio de Janeiro, para tristeza dos intelectuais, como sugerem as últimas linhas de Ś́lvio Romero. Em vários textos críticos do período, a palavra "decadência" foi utilizada para se descrever o teatro da época, cada vez mais distanciado da literatura, voltado apenas para o entretenimento. É bastante conhecido o balanço que Machado de Assis fez do teatro brasileiro em 1873, no artigo "Instinto de Nacionalidade": "Hoje, que o gosto público tocou o último grau da decadência e perversão, nenhuma esperança teria quem se sentisse com vocação para compor obras severas de arte. Quem lhas receberia, se o que domina é a cantiga burlesca ou obscena, o cancã, a mágica aparatosa, tudo o que fala aos instintos inferiores?" (Machado de Assis, 1951, p. 150).

Seria longo e cansativo discutir os outros capítulos da História da Literatura Brasileira de Romero, nos quais ele aborda a produção dramática dos escritores românticos. Nesta altura, basta enfatizar o que ficou evidenciado nas linhas acima: a sua concepção de dramaturgia como parte da literatura.
Em 1916, José Veríssimo publica a sua História da Literatura Brasileira, com um viés bastante diferente da de seu desafeto Sílvio Romero. ${ }^{7}$ Diante do caráter abrangente da obra que precedeu a sua, na qual entravam literatos, publicistas, oradores, jurisconsultos, moralistas, economistas e historiadores, observa que, "sendo mais que uma história da literatura", ela é "quase uma história da nossa cultura”. E pergunta se cabe à história da literatura "comportar tudo quanto na ordem intelectual se escreveu no Brasil, ou, como penso, somente o que é propriamente literário ou o que, não o sendo, tem bastante generalidade e virtudes de emoção e de forma para poder ser incorporado na literatura?” (Veríssimo, 1977, p. 115).

Para José Veríssimo, a literatura englobava apenas os escritos que tinham finalidade artística. E a crítica, por sua vez, devia ter por base, em primeiro lugar, critérios estéticos. Como observa Antonio Candido, tais critérios são "visíveis na sua preocupação pela coerência da narrativa, a organização da obra, a lógica do personagem, a pertinência da linguagem", enquanto que na obra de Sílvio Romero encontram-se critérios não-estéticos, como "fidelidade ao real, sentimento da vida, sinceridade, valentia da emoção, função nacional do texto e outros" (Candido, 1978, p. xxiv). José Veríssimo, na "Introdução" à sua História da Literatura Brasileira, estabelece as diferenças que existiam entre ambos:

A História da Literatura Brasileira do Sr. Dr.
Sílvio Romero é sobretudo valiosa por ser o
primeiro quadro completo não só da nossa
literatura mas de quase todo o nosso trabalho
intelectual e cultura geral, pelas idéias gerais e

7 Nesta parte aproveito alguns trechos do que escrevi no estudo "Sílvio Romero, José Veríssimo e o teatro brasileiro", publicado em O Teatro na Estante. Cotia, Ateliê, 1998. 
vistas filosóficas que na história da nossa literatura introduziu, e também pela influência excitante e estimulante que exerceu em a nossa atividade literária de 1880 para cá.

Com diverso conceito do que é literatura, e sem fazer praça de filosofia ou estética sistemática, aponta esta apenas a fornecer aos que porventura se interessam pelo assunto uma noção tão exata e tão clara quanto em meu poder estiver, do nosso progresso literário, correlacionado com a nossa evolução nacional. E foi feita, repito-o desenganadamente, no estudo direto das fontes, que neste caso são as mesmas obras literárias, todas por mim lidas e estudadas, como aliás rigorosamente me cumpria (Veríssimo, 1969, p. 16-7).

Contrário ao nacionalismo como critério de valor e à ideia de que a obra literária se realiza enquanto documento social, José Veríssimo define a literatura como "arte literária". E acrescenta: "Somente o escrito com o propósito ou a intuição dessa arte, isto é, com os artifícios de invenção e de composição que a constituem é, a meu ver, literatura" (idem, p. 10).

Apesar das divergências, aproximam-se ao considerarem a produção dramática do século XIX como parte da produção literária. "Um escritor - afirma Veríssimo - não pode ser bem entendido na sua obra e ação senão visto em conjunto, e não repartido conforme os gêneros diversos em que provou o engenho" (idem, p. 15). Assim, examina os escritores românticos levando em conta poemas, romances e peças de teatro que tenham escrito. Vimos que esse foi também o procedimento de Romero. Ao final do volume, Veríssimo faz novas reflexões sobre a dramaturgia brasileira, numa síntese intitulada "O teatro e a literatura dramática".

Separam-se os historiadores nos julgamentos. Veríssimo não vê a obra de Martins Pena com o mesmo entusiasmo. Elogia as qualidades puramente teatrais do autor, que sabia combinar os efeitos cômicos, dispor as cenas etc., mas observa, numa frase reveladora de suas restrições: "Martins Pena não é senão isto, um escritor de teatro" (p.254), diminuindo assim o valor literário do criador da comédia brasileira.

Em relação ao período colonial, podemos dizer que ambos foram prejudicados pelo desconhecimento de aspectos do nosso teatro que só foram revelados por pesquisas posteriores. Hoje, quando lemos os ensaios de Décio de Almeida Prado reunidos no livro Teatro de Anchieta a Alencar, temos uma boa noção acerca das nossas primeiras manifestações teatrais e da própria construção do teatro brasileiro ao longo do tempo. Veríssimo afirma que nossa literatura dramática só vai nascer no Brasil com Gonçalves de Magalhães e Martins Pena, no romantismo. Deixando de lado as poucas produçôes coloniais, discorda do critério nacionalista de Romero e não inclui Antonio José da Silva em nossa história literária. Afinal, o "infeliz e engenhoso Antonio José” exerceu toda a sua atividade literária em Portugal, completamente alheio ao que se passava no Brasil.

As divergências entre ambos podem ser medidas na leitura de dois parágrafos que se encontram em suas obras. Leiamos Romero:

Não possuímos obras de romancistas que, em seu gênero, sejam superiores ao Demônio Familiar e Mãe, de Alencar, à Matilde e Calabar, de Agrário, à Torre em Concurso, de Macedo, ao Antônio José, de Magalhães, às Doutoras, de França Júnior, ao Noviço e Judas em Sábado de Aleluia, de Pena. Quase outro tanto se poderia afirmar da História de uma Moça Rica, de Pinheiro Guimarães, de Leonor de Mendonça, de Gonçalves Dias, das Coisas da Moda, de Joaquim Serra” (Romero, 1901, p. 62).

Veríssimo discorda completamente desse ponto de vista e afirma que, ao contrário, a dramaturgia brasileira "não deixou de si nenhum documento equivalente aos que nos legou o romantismo no romance ou na poesia". E mais: "A literatura dramática brasileira nada conta, ao meu ver, que valha o Guarani ou a Iracema, a Moreninha ou as Memórias de um Sargento de Milícias, a Inocência ou Brás Cubas, os Cantos 
de Gonçalves Dias ou os poemas da segunda geração romântica" (Veríssimo, 1969, p. 258).

Às palavras de Veríssimo, Romero poderia retrucar com os argumentos expostos em seu "Quadro sintético da evolução dos gêneros na literatura brasileira", no qual afirma que "a história da nossa dramaturgia é que não tem sido feita com o cuidado, o desvelo, o amor que fora para desejar (...). Ninguém lê dramas e comédias, ou os lê rarissimamente" (Romero, 1985).

O fato é que as diferentes avaliações resultam dos diferentes conceitos de literatura que cada um adotou. Romero faz poucas restrições à dramaturgia brasileira e valoriza principalmente o gênero cômico, porque o vê como documento de uma época. Tal entusiasmo, evidentemente, não era compartilhado por Veríssimo. Sua preferência era pelo texto teatral com valor literário, como se percebe, por exemplo, nos elogios dirigidos às comédias de Machado de Assis. A seu ver, as peças de estréia do escritor eram notáveis "pelas qualidades de espírito e composição" e Não Consultes Médico era um sainete "digno de Musset..., excelente como literatura" (Veríssimo, 1969, p. 278 e 289). Veríssimo elogia o estilo elegante do jovem Machado e observa que suas comédias não tinham grande valor teatral. Não se tratava exatamente de uma restrição. Ao autor de Dom Casmurro faltavam "as qualidades, sobretudo as inferiores, as habilidades do ofício de autor dramático, a acomodação ao gosto público e à perspectiva particular da rampa, uma porção de dons somenos, mas essenciais ao bom sucesso na arte inferior que é o teatro" (idem, p. 289).

Não nos assustemos com o adjetivo. Desde que Aristóteles, na Poética, atribuiu uma importância secundária ao espetáculo teatral, criou-se uma tradição que só os movimentos de vanguarda da virada do século XIX e os tempos modernos conseguiram abalar. Veríssimo tinha atrás de si toda a história do teatro, escrita preferencialmente pelo ângulo da literatura dramática. E tinha também um modelo de história da literatura, na qual o teatro só era comentado enquanto texto: a Histoire de la Littérature Fran- çaise, de Gustave Lanson, publicada em 1894 e citada na "Introdução" à sua História da Literatura Brasileira. Para Veríssimo, o espetáculo teatral era um entrave à realização literária de uma peça. Quando escrita para ser representada, esta terá diante de si uma platéia "que será sempre em maioria composta de ignaros ou simples, para que lhe não bastem as qualidades propriamente literárias" (Veríssimo, 1969, p. 290).

Romero, que tinha menor acuidade para os elementos estéticos do texto literário, não discordava desse ponto de vista, como vimos em seu comentário a uma passagem do prólogo de Gonçalves dias a Leonor de Mendonça.

Como se vê, tanto Veríssimo quanto Romero encaram o teatro em sua dupla natureza: como texto e como espetáculo. Mas, fiéis aos postulados do seu tempo, estabelecem uma hierarquia, valorizando em primeiro lugar o aspecto literário da peça teatral. Se pensam da mesma maneira, quanto a esse aspecto particular, separam-se, porém, na metodologia, nas análises, interpretações e, muitas vezes, nos juízos de valor. Há pouco, vimos os elogios de Veríssimo aos aspectos literários das comédias de Machado de Assis. Pois Sílvio Romero praticamente as ignora, dedicando-lhes apenas duas linhas, nas quais afirma que "são contos dialogados sem vida autônoma, sem as vantagens da novelística” (Romero, 1985, p. 1515). Na verdade, as restrições que se acumulam no capítulo dedicado ao conjunto da obra de Machado de Assis são um primor de miopia crítica.

Para encerrar, um último paralelo pode ser estabelecido entre Veríssimo e Romero. Ambos consideram o período romântico como o mais rico da nossa dramaturgia, englobando aí a produção feita sob inspiração do realismo teatral francês. Destacam as obras dramáticas de Gonçalves de Magalhães, Martins Pena, Gonçalves Dias, Joaquim Manuel de Macedo e José de Alencar. Em segundo plano, referem-se a autores como Luís Antonio Burgain, Joaquim Norberto, Varnhagen, Teixeira e Sousa, Álvares de Azevedo, Quintino Bocaiúva, Aquiles Varejão, Agrário de Meneses, Pinheiro Guimarães, 
Castro Alves, Taunay, Franklin Távora e França Júnior. Ślvio Romero, mais prolixo, cita vários trechos de peças para exemplificar a arte de um determinado autor. Veríssimo, mais conciso, não só é mais rigoroso nas análises, como mais inteligente nos comentários sucintos e certeiros que faz.

Do teatro que lhes foi contemporâneo nas duas décadas finais do século XIX, pouco disseram. Ambos lamentaram o desaparecimento da dramaturgia de cunho literário e sua substituição pelas peças do gênero cômico e musicado. Veríssimo considerava que o teatro brasileiro, era produto do romantismo e com ele tinha-se finado. Apenas de passagem, pois, referiu-se a Artur de Azevedo e a alguns companheiros de geração, como Valentim Magalhães, Urbano Duarte ou Moreira Sampaio, afirmando que tinham condições de fazer boa literatura dramática, mas que foram empurrados pelos empresários e pelo público aos gêneros pouco nobres do teatro comercial: revistas de ano, paródias, operetas, burletas etc.

Em que pesem algumas perspectivas críticas que envelheceram ou mesmo alguns conceitos ultrapassados, as obras de Romero e Veríssimo são fontes indispensáveis para o estudo do teatro brasileiro. À falta de um grande historiador que tivesse se dedicado unicamente ao teatro entre nós no século XIX, é nelas que vamos colher as primeiras visóes sistematizadas acerca do gênero dramático. Podemos acrescentar também que essas obras são a base de onde partiram as demais histórias da literatura brasileira escritas em seguida, ao longo de várias décadas. Por essa razão demorei-me no comentário acerca da visão que ambos têm da dramaturgia como parte da literatura.

\section{4}

Nesta altura do nosso percurso, podemos nos perguntar: as histórias da literatura brasileira que se seguiram às de Romero e Veríssimo levam em conta a dramaturgia feita no país?
Vou correr o risco de cometer alguma injustiça, porque não consultei todas as histórias da nossa literatura. Há algumas muito fracas, pequenas sínteses ginasiais, obras didáticas que não nasceram de pesquisas e leituras críticas consistentes. $\mathrm{O}$ que posso garantir é que li as mais importantes, começando pela de Ronald de Carvalho, Pequena História da Literatura Brasileira, datada de 1919 e, segundo Otto Maria Carpeaux, calcada em Romero e Veríssimo (Carpeaux, 1964, p. 24).

Ronald de Carvalho nada acrescenta no que diz respeito ao período colonial. Faz apenas rápidas menções a Anchieta e Botelho de Oliveira e, seguindo Romero, inclui Antônio José em nossa literatura, analisando algumas das suas peças. Ainda que o comediógrafo tenha vivido em Portugal e escrito para portugueses, pondera que ele "merece, contudo, pelo nascimento, uma referência na história do nosso pensamento" (Carvalho, 1968, p. 139). Quanto ao arcadismo, repete as informaçōes já conhecidas sobre Alvarenga Peixoto, que teria escrito um drama, Eneias no Lácio, e traduzido a Merope, de Maffei.

Ao abordar o romantismo, afasta-se de Romero e Veríssimo, estudando a produção literária do período por gêneros, e não pelo conjunto da obra de um determinado escritor. À poesia, ele dedica 42 páginas; ao romance, 16 , à história e crítica, 7; à dramaturgia, duas páginas e meia. Nesse pequeno capítulo intitulado "Teatro" apenas a obra de Martins Pena é brevemente analisada. São feitas rápidas menções à dramaturgia de Gonçalves de Magalhães, Teixeira e Souza, Gonçalves Dias, Joaquim Norberto, Araújo Porto-Alegre, Varnhagen, José de Alencar e Joaquim Manuel de Macedo. Para se ter uma ideia mais precisa da superficialidade com que a dramaturgia é considerada, basta dizer que apenas dois títulos de peças são mencionados: Antônio José ou o Poeta e a Inquisição e O Juiz de Paz da Roça.

Em relação às histórias literárias de Romero e Veríssimo, a perda é tanto quantitativa quanto qualitativa para a dramaturgia que, ape- 
sar de ser considerada parte da literatura brasileira, é estudada como se fosse a prima pobre do romance e da poesia. Ao tratar da literatura entre 1870 e 1900, repete-se o procedimento. Ronald de Carvalho dedica apenas dois parágrafos à dramaturgia, sem analisar qualquer peça e reiterando o caráter "decadente" do nosso teatro, no qual predominou "o ato ligeiro, a burleta, a comédia trivial, a revista popular e anedótica de Artur Azevedo, Valentim Magalhães, Moreira Sampaio e muitíssimos outros" (Carvalho, 1968, p. 332).

Depois da Pequena História da Literatura Brasileira de Ronald de Carvalho surgiram algumas histórias literárias sem muito valor, segundo Otto Maria Carpeaux (cf. Carpeaux, 1964). Algumas trazem erros de informação, outras são rápidos resumos da evolução histórica, outras são de teor fortemente didático, de modo que podemos considerar a História da Literatura Brasileira. Seus Fundamentos Econômicos, de Nelson Werneck Sodré, de 1938, como a próxima a merecer nossa atenção. Afinal, essa obra foi reeditada várias vezes, ao contrário de outras da mesma época, que não passaram da primeira edição. Para o estudioso da literatura dramática, porém, o autor é uma decepção. Antes de tudo, por negar a Anchieta um lugar na história da literatura brasileira, alegando que ele escreveu ora em tupi, ora na língua geral, com intenções catequéticas. Depois, porque dedica à dramaturgia alguns poucos parágrafos, fazendo considerações genéricas sobre autores do século XIX e não analisando uma peça teatral sequer em sua volumosa obra. Nenhuma linha é escrita sobre a dramaturgia das primeiras décadas do século XX, lacuna que não é preenchida nem mesmo nas edições posteriores à primeira, como se vê na sexta edição, de 1976. Pode-se dizer que Nelson Werneck Sodré baniu a dramaturgia da história da literatura brasileira, desconsiderando-a por completo, ao contrário do que haviam feito Romero e Veríssimo. Não há, na obra, nenhuma explicação para o veto imposto à dramaturgia.
Em 1939, duas outras histórias da literatura brasileira foram publicadas: a de Bezerra de Freitas (cf. Freitas, 1939) e a de José Osório de Oliveira. A primeira não é muito mais que uma síntese escolar e, em relação ao teatro ou à dramaturgia, é tão pobre quanto à de Nelson Werneck Sodré. Em toda a obra, apenas duas páginas trazem algumas informaçōes sobre a dramaturgia do século XIX, e de maneira incompleta. Nenhuma peça teatral é estudada. $\mathrm{Na}$ História Breve da Literatura Brasileira, do português José Osório de Oliveira a dramaturgia também é completamente deixada de lado. Quando aborda o período colonial, o autor não vê nem Anchieta nem Antônio José como escritores brasileiros. Um único parágrafo é dedicado ao teatro, quando estuda o modernismo:

Só no teatro, apesar das tentativas de um cronista sutil: Álvaro Moreyra, apesar dos êxitos de Joracy Camargo, apesar das experiências de Oswald de Andrade e de Flávio de Carvalho, o homem brasileiro não encontrou ainda quem o exprimisse. Talvez, com o seu feitio de cronista de costumes, que o aparenta ao folhetinista França Júnior, tenha conseguido mais do que qualquer outro, nesse campo, o Marques Rebêlo de Rua Alegre, 12 - criação teatral especificamente, não diremos brasileira, mas carioca (Oliveira, 1956, p. 132-3).

A dramaturgia brasileira ganha um pouco mais de atenção na Breve História da Literatura Brasileira, de Érico Veríssimo, publicada nos Estados Unidos em 1945. Não muita, como se vê no parágrafo dedicado ao teatro romântico; "A safra teatral durante o período do Romantismo, no Brasil, foi muito magra. Entre os poucos dramaturgos da época só um merece ser lembrado, Martins Pena. Escreveu peças de costumes nas quais tentou retratar a sociedade brasileira contemporânea” (Veríssimo, 1995, p. 58).

$\mathrm{O}$ período posterior também não teve muita sorte: Érico destaca apenas Artur Azeve- 
do, em algumas poucas linhas. Em compensação, o teatro dos anos 1930-1940 ganha alguns parágrafos, com destaque para Joracy Camargo, Ernani Fornari, Maria Jacinta, Oduvaldo Vianna, Carlos Lacerda, Raimundo Magalhães Júnior, Renato Vianna e Oswald de Andade. Érico leu várias peças desses autores e as comenta sucintamente. Sobre Oswald, que só foi encenado nos anos 1960, escreveu: "As peças sociais de Oswald de Andrade são repletas de alegorias e seu humor tem uma qualidade surrealista (...). Ousado experimentalista, homem apaixonado por aventuras intelectuais, nunca tem medo de dar saltos mortais pelos ares" (Veríssimo, 1995, 125).

A dramaturgia volta a ganhar destaque na obra de Antônio Soares Amora, publicada em 1955. Sua História da Literatura Brasileira teve várias edições, comprovando a boa aceitação entre especialistas, professores e estudantes de Letras. Sem ser volumosa, dá conta de toda a nossa produção literária em bons capítulos sintéticos sobre movimentos, autores e obras. A dramaturgia comparece desde o início, com comentários sobre os autos de Anchieta. Manuel Botelho é estudado apenas como poeta e Antônio José é considerado escritor da literatura portuguesa. Um capítulo intitulado "Teatro" dá conta da produção dramática dos tempos românticos, com destaque para Martins Pena. No estudo do modernismo, uma pequena síntese comenta as dificuldades enfrentadas pelo teatro nos anos 1920-1930, com o reconhecimento das primeiras inovações estéticas feitas nesse terreno por Álvaro Moreyra e seu "Teatro de Brinquedo", pelas peças de Oswald de Andrade e pela "ação renovadora de um Nelson Rodrigues, com Vestido de Noiva, 1943" (Amora, 1977, p. 178). Na edição que consultei, a 9a., de 1977 , o autor dedicou ainda um parágrafo à dramaturgia nos anos 1950 e início dos anos 1960, animado com o aparecimento de bons dramaturgos como Abílio Pereira de Almeida, Silveira Sampaio, Jorge Andrade, Ariano Suassuna, Gianfrancesco Guarnieri, Dias Gomes e alguns outros.
Seria desejável que o autor ampliasse os seus comentários, claro. Mas todo o livro é na verdade uma síntese da nossa história literária, com detalhadas notas bio-bibliográficas sobre nossos principais escritores.

A mais ambiciosa de todas as nossas histórias da literatura brasileira é também da década de 1950. Entre 1955 e 1959, em quatro volumes com mais de duas mil páginas escritas por vários colaboradores, foi publicada $A$ Literatura no Brasil, sob a direção de Afrânio Coutinho. Em dez anos, esgotaram-se os vinte mil exemplares da primeira edição. A segunda, revista e ampliada, saiu em 1968, com seis volumes. Trata-se, portanto, de uma importantíssima obra de referência, que teve boa receptividade porque procurou renovar os estudos literários e particularmente o modo de escrever histórias da literatura. Em relação às obras do passado, inovou ao fazer a periodização da nossa literatura por critérios estilísticos, centralizando o pensamento crítico na análise das obras, entendidas como literatura e não documentos culturais.

O estudioso da dramaturgia brasileira encontrará boas páginas de crítica nesses volumes. No primeiro, Armando Carvalho examina os autos do Padre Anchieta, detendo-se em alguns deles para uma análise mais cuidadosa. Pela primeira vez em uma história da nossa literatura podemos ler um bom estudo das comédias Hay Amigo para Amigo e Amor, Engaños e Celos, de Botelho de Oliveira, feito por Eugênio Gomes. Antônio José não é estudado; definitivamente, passa a fazer parte apenas da literatura portuguesa.

O melhor de A Literatura no Brasil, para o estudioso do teatro brasileiro, é o capítulo "A Evolução da Literatura Dramática”, de Décio de Almeida Prado. Escrito por um especialista que tinha uma extraordinária capacidade crítica, começa pelo estudo dos autos de Anchieta e chega até o teatro brasileiro dos anos 1950. Pela qualidade das análises e interpretações, esse texto serviu de base para J. Galante de Sousa escrever e publicar em 1960 uma obra fundamental de nossa historiografia teatral: O Teatro no Brasil. 
Não podemos deixar de mencionar, aqui, uma obra que, sem ser uma história completa da literatura brasileira, porque trata de apenas dois períodos, é um estudo de caráter historiográfico que lemos ainda hoje com admiração: a Formação da Literatura Brasileira, de Antonio Candido, publicada em 1959 pela editora Martins. Como se sabe, o autor debruçou-se sobre os dois momentos que ele denomina "decisivos" para a formação da literatura brasileira: o Arcadismo e o Romantismo. As análises e interpretações de poemas e romances são sempre de primeira linha, o que nos faz voltar sempre aos dois volumes quando queremos, por exemplo, reler as boas páginas sobre Alencar ou Gonçalves Dias. Infelizmente Antonio Candido não tratou do teatro. Não que não considere a dramaturgia como parte da literatura. É que, explica no prefácio, o preparo do livro foi feito por etapas, ao longo do tempo, em meio a outros trabalhos, seguindo um plano previamente fixado, no qual não constava a análise da dramaturgia. A seu ver, porém, a exclusão do teatro, que lhe pareceu inicialmente "recomendável para a coerência do plano", resultou num "empobrecimento", como verificou ao final do trabalho. Ele explica:

O estudo das peças de Magalhães e Martins Pena, Teixeira e Souza e Norberto, Porto-Alegre e Alencar, Gonçalves Dias e Agrário de Menezes teria, ao contrário, reforçado meus pontos de vista sobre a disposição construtiva dos escritores, e o caráter sincrético, não raro ambivalente, do Romantismo. Talvez o argumento da coerência tenha sido uma racionalização para justificar, aos meus próprios olhos, a timidez em face dum tipo de crítica - a teatral - que nunca pratiquei e se torna, cada dia mais, especialidade amparada em conhecimentos práticos que não possuo (Candido, s/d, Vol. 1, p. 12).

As palavras de Antonio Candido talvez expliquem o que vem acontecendo nas histórias da literatura brasileira escritas a partir dos anos 1960: cada vez mais, com poucas exceções, a dramaturgia é estudada com parcimônia, como se fosse um apêndice da nossa história literária. Por vezes, nem mesmo é levada em conta. A exigência de um instrumental teórico e analítico próprio, que nem sempre é do domínio de quem estuda a poesia e a prosa, e o diálogo dos nossos dramaturgos com seus pares europeus e norte-americanos - o que exige o conhecimento de suas obras - são dificuldades que afastam os historiadores da literatura brasileira da dramaturgia.

Essas dificuldades estão presentes na série A Literatura Brasileira, da coleção "Roteiro das Grandes Literaturas", publicada pela Cultrix nos anos 1960, em seis volumes. Nos três primeiros há ainda algumas páginas sobre nossa dramaturgia. José Aderaldo Castello, em Manifestações Literárias do Periodo Colonial estuda os autos de Anchieta, nesta altura já editados. Antônio Soares Amora, em $O$ Romantismo dedica um bom número de páginas ao estudo das peças de Martins Pena, Gonçalves Dias e José de Alencar. É um capítulo menos completo do que os escritos sobre a prosa e a poesia, mas as análises são muito boas, especialmente a dedicada a Martins Pena, na qual o autor estabelece um paralelo entre a obra do nosso primeiro comediógrafo e Debret. No volume O Realismo, João Pacheco dá apenas breves informações sobre a dramaturgia do período, lembrando os nomes de Martins Pena, Quintino Bocaiúca e o Visconde de Taunay. França Júnior e Artur Azevedo merecem apenas um parágrafo cada. Nos demais volumes da série - O Simbolismo, de Massaud Moisés; O Pré-modernismo, de Alfredo Bosi; O Modernismo, de Wilson Martins - a dramaturgia simplesmente desaparece.

As dificuldades apontadas acima talvez expliquem também por que a história da literatura brasileira mais bem-sucedida de todas que já foram escritas aborde com muita parcimônia a nossa produção dramática. Refiro-me à História Concisa da Literatura Brasileira, de Alfredo Bosi, publicada em 1970, e que já teve mais de quarenta edições. 
Nessa obra de cabeceira de todos nós há boas páginas sobre os autos de Anchieta e sobre as peças de Martins Pena, Gonçalves Dias, José de Alencar, Agrário de Menezes e Paulo Eiró. Depois, é examinada a dramaturgia de Artur Azevedo e de Machado de Assis. O estudioso do teatro brasileiro fica satisfeito ao ver um crítico do calibre de Alfredo Bosi se debruçar sobre o principal da nossa produção dramática do século XIX, considerando-a como parte da literatura. Mas se decepciona ao constatar que nenhuma linha é dedicada à dramaturgia do século XX.

Se prosseguirmos em nosso caminho em direção às demais histórias da literatura brasileira escritas nos últimos quarenta anos, a tendência de suprimir a dramaturgia se acentua. Nas obras que abordam desde as origens da literatura brasileira até os tempos modernos e contemporâneos, parece não haver problema em comentar, ainda que com brevidade, a produção dramática da colônia e do século XIX. As dificuldades surgem quando se trata de abordar a dramaturgia moderna e contemporânea. Sirva de exemplo a História da Literatura Brasileira de Massaud Moisés, em cinco volumes (1985-1989). No primeiro volume ele estuda os autos de Anchieta e as comédias de Botelho de Oliveira. No segundo, o teatro do período romântico é sucintamente analisado. E pela primeira vez uma história da literatura brasileira, salvo engano, incorpora o dramaturgo gaúcho Qorpo Santo. No terceiro, sobre o realismo, França Júnior e Artur Azevedo são brevemente estudados. Já no quarto volume, dedicado ao simbolismo, o teatro desaparece. E no quinto, que trata da literatura a partir do movimento modernista, chegando até os anos 1980, a dramaturgia também é esquecida. Para não fazer injustiça ao autor, ressalvo que há uma página sobre as peças de Oswald de Andrade e um parágrafo sobre a Rachel de Queiroz dramaturga.

Entre todas as histórias da literatura brasileira publicadas nos últimos cinquenta anos, a de Luciana Stegagno Picchio, de 1997, é a úni- ca que traz informações e análises, ainda que muito rápidas, da nossa dramaturgia, desde Anchieta até os anos 1970. Autora de uma importante História do Teatro Português, a familiaridade com o gênero dramático e o interesse por essa forma de arte foram fatores decisivos para que ela incluísse em sua História da Literatura Brasileira vários dramaturgos brasileiros do passado e do presente. São sempre corretos e bem argumentados os comentários sobre nossos autores do período colonial e do século XIX. Surpreende a atenção dada à dramaturgia do prémodernismo, que nunca tinha sido considerada nas nossas histórias da literatura: Goulart de Andrade, João do Rio, Roberto Gomes, Paulo Gonçalves, Graça Aranha, Cláudio de Souza e Gastão Tojeiro. Igualmente são incluídos os dramaturgos dos anos 1920-1940: Armando Gonzaga, Viriato Corrêa, Oduvaldo Vianna, Renato Vianna, Álvaro Moreyra e Oswald de Andrade, cujas peças ganham mais atenção. É uma pena que os comentários sejam muito sucintos, dando uma ideia apenas razoável acerca da dramaturgia que precedeu o teatro moderno entre nós. Na sequência, no capítulo intitulado "Teatro, música, cinema. A crítica. O estilo brasileiro", encontramos o mesmo defeito: poucas linhas para dar conta da dramaturgia de Nelson Rodrigues, Jorge Andrade, Ariano Suassuna, Gianfrancesco Guarnieri, Oduvaldo Vianna Filho, Augusto Boal, Plínio Marcos e tantos outros que são apenas citados.

Dois anos depois da História da Literatura Brasileira, de Luciana Stegagno Picchio, José Aderaldo Castello publica, em dois volumes, $A$ Literatura Brasileira: Origens e Unidade, obra em que estuda nossa literatura, das origens até os anos sessenta do século XX. Deliberadamente, o autor descarta a dramaturgia, que só aparece mencionada nos casos de Anchieta e Botelho de Oliveira, no período colonial, e de Gonçalves de Magalhães, no romantismo. Um breve comentário sobre Antônio José ou o Poeta e a Inquisição antecede o único parágrafo dedicado ao teatro romântico: 
Quanto ao teatro - aqui referido apenas em virtude de ter sido envolvido pelas discussōes da reforma romântica -, o destaque que lhe damos provém, no caso, da proposta teórica de Magalhães, permanecendo o mais nos limites da história. Mesmo que apenas para lembrar, citemos João Caetano, ator e também teórico da dramaturgia, Martins Pena, e com este outros dramaturgos ou comediógrafos do momento, José de Alencar, Joaquim Manuel de Macedo. Mas a implantação do gênero entre nós, à parte as manifestações do Período Colonial, seria desde cedo marcada por crise discutida e denunciada por um Álvares de Azevedo ou pelo nosso melhor crítico, também de teatro, de meados do século, Machado de Assis (Castello, 1999, Vol. 1, p. 222-3).

Nenhuma outra linha é escrita sobre a dramaturgia brasileira. Quase o mesmo se poderia dizer da História da Literatura Brasileira de Carlos Nejar, de 2007. O autor faz rápidas menções a peças e autores do período romântico e dos tempos modernos, mas sem desenvolver qualquer análise ou interpretação. exposto?

$\mathrm{O}$ que concluir depois de tudo que foi

Este percurso pelas histórias da literatura brasileira me faz pensar o seguinte: a inclusão da dramaturgia em todas as obras aqui mencionadas nunca é plenamente satisfatória. Claro que há boas páginas críticas aqui e ali, como aliás reconheci mais de uma vez. Mas a impressão que fica é que a dramaturgia, quando não é deixada de lado, parece entrar na história literária como uma parente meio distante da poesia e da prosa. O historiador se sente na obrigação de incluí-la em sua obra, porque afinal parece que a dramaturgia faz mesmo parte da literatura uma peça, "quando lida e mesmo recitada, é literatura; mas quando representada, passa a ser teatro", lembra Anatol Rosenfeld (cf. 1976, p. 24) -, mas a trata sem profundidade, limitando-se a comentários sintéticos e a informações genéricas. Essa é a tendência geral. Tudo indica que uma divisão de tarefas foi silenciosamente estabelecida ao longo do século XX, sem qualquer discussão de caráter teórico e crítico: o historiador da literatura brasileira tomou para si o trabalho de discorrer sobre poemas, contos e romances, enquanto o historiador do teatro ou da dramaturgia procurou aprofundar o estudo da peça teatral. Que essas palavras não sejam tomadas como uma queixa, mas como uma constatação. Sílvio Romero e José Veríssimo foram os únicos a tratar as peças teatrais com a mesma atenção dada à poesia e à prosa. A partir de Ronald de Carvalho, como se viu, o espaço reservado à dramaturgia diminuiu sensivelmente.

Os futuros historiadores da literatura brasileira deverão levar em conta o quadro acima traçado. Poderão optar por dar continuidade ao padrão estabelecido no decorrer do século XX ou escrever obras em que ficcionistas, poetas e dramaturgos sejam estudados em pé de igualdade. No segundo caso, talvez seja necessário retomar a proposta de Afrânio Coutinho e acreditar que uma nova e mais completa história da literatura brasileira deve ser uma obra coletiva, escrita por algumas dezenas de especialistas, dada a enorme dimensão da nossa produção literária. Por outro lado, há que se considerar também que, ainda que a dramaturgia não encontre um lugar nas futuras histórias da literatura, isso não significa desconsiderar o possível caráter literário das peças teatrais. Assumida a divisão de trabalho a que me referi há pouco, sempre restará a essa forma artística que pode ser lida e estudada enquanto parte da literatura, ou apreciada como parte de um espetáculo teatral, um lugar onde será analisada e interpretada em profundidade: nas histórias do teatro ou nas histórias da dramaturgia. 


\section{Referências bibliográficas}

AMORA, Antônio Soares. História da Literatura Brasileira. 9a ed. Saraiva, 1977.

CANDIDO, Antonio. "Introdução". In: Silvio Romero: teoria, crítica e história literária. Rio de Janeiro, Livros Técnicos e Científicos; São Paulo, Ed. da Universidade de São Paulo, 1978. Formação da Literatura Brasileira. 4a ed. São Paulo, Martins, s/d.

CARPEAX, Otto Maria. Pequena Bibliografia Critica da Literatura Brasileira. Rio de Janeiro, Letras e Artes, 1964.

CARVALHO, Ronald de. Pequena História da Literatura Brasileira. 13a ed. Rio de Janeiro, Briguiet, 1968.

CASTELLO, José Aderaldo. A Literatura Brasileira: Origens e Unidade. São Paulo, Edusp, 1999.

FARIA, João Roberto. Idéias Teatrais: o Século XIX no Brasil. São Paulo, Perspectiva/Edusp, 2001.

FERNANDES PINHEIRO, Joaquim Caetano. Curso Elementar de Literatura Nacional, Rio de Janeiro, Garnier, 1862, p. 455.

FREITAS, Bezerra de. História da Literatura Brasileira. Porto Alegre, Globo, 1939.

MACHADO DE ASSIS. Crítica Literária. Rio de Janeiro, Jackson, 1951.

NEJAR, Carlos. História da Literatura Brasileira. Rio de Janeiro, Relume Dumará/Copesul/Telos, 2007.

OLIVEIRA, José Osório de. História Breve da Literatura Brasileira. Nova edição, revista e aumentada. São Paulo, Martins, 1956.

ROMERO, Sílvio. História da Literatura Brasileira. 2a ed. Rio de Janeiro, Garnier, v. 1, 1902.

. História da Literatura Brasileira. 2a ed. Rio de Janeiro, Garnier, v. 2, 1903.

. História da Literatura Brasileira. 7a ed. Rio de Janeiro, José Olympio/INL-MEC, v. 4, 1980.

. História da Literatura Brasileira. 7a ed. Rio de Janeiro, José Olympio/INL-MEC, v. 5, 1985. . Martins Pena. Porto, Chardron, 1901.

ROSENFELD, Anatol. Texto/Contexto. 3a ed. São Paulo, Perspectiva, 1976.

VERÍSSIMO, Érico. Breve História da Literatura Brasileira. São Paulo, Globo, 1995.

VERÍSSIMO, José. História da literatura brasileira. 5a ed. Rio de Janeiro, José Olympio, 1969.

José Veríssimo: teoria, crítica e história literária. Seleção e apresentação de João Alexandre Barbosa. Rio de Janeiro/São Paulo, Livros Técnicos e Científicos/Edusp, 1977.

WOLF, Ferdinand. O Brasil Literário: História da Literatura Brasileira. Trad. de Jamil Almansur Haddad. São Paulo, Companhia Editora Nacional, 1955. 